\title{
From babbling to first words in Tashlhiyt language acquisition: longitudinal two-case studies
}

\author{
MOHAMED LAHROUCHI \\ Structures Formelles du Langage (UMR 7023, Université Paris 8) \\ mohamed.lahrouchi@cnrs.fr
}

and

SOPHIE KERN

Laboratoire Dynamique du Langage (UMR 5596, Université Lyon 2)

sophie.kern@cnrs.fr

\begin{abstract}
Strong similarities observed between babbling and first words suggest a universal foundation of word production in children. The aim of this work was to evaluate the role of biomechanical constraints on babbling and first words production in two children acquiring Tashlhiyt, a Berber language spoken in Morocco. When considering isolated sounds and syllable types, our data provided evidence for a universal basis for early vocal patterns. The subjects produced more stops, more coronals and labials, vowels preferentially belonging to the lower left part of the vowel space, and open syllables. However, they only partially confirmed the existence of the preferred $\mathrm{CV}$ combinations generally observed in the early production of children learning various languages. The comparison between babbling and first words revealed a linguistic continuity between the two periods but also some increasing complexity and diversification in the words, which can be explained by an increase of articulatory capacities.
\end{abstract}

Keywords: Babbling, first words, Tashlhiyt, biomechanical constraints, continuity

\section{Résumé}

Les importantes similarités constatées dans les productions du babillage et les premiers mots suggèrent une base universelle commune. Ce travail a pour but d'évaluer le rôle des contraintes biomécaniques sur le babillage et les premiers mots de deux enfants apprenant le tachelhit, une langue berbère parlée au Maroc. Au chapitre des sons en isolation et des structures syllabiques, nos résultats soutiennent l'hypothèse d'un fondement universel en matière de configurations vocaliques précoces : les sujets de notre étude produisent plus d'occlusives, plus de coronales et de labiales; ils préfèrent les voyelles de la partie inférieure gauche de l'espace vocalique ainsi que les syllabes ouvertes. Mais les résultats n'ont confirmé que partiellement l'existence des 
associations $\mathrm{CV}$ décrites comme utilisées de manière préférentielle par les enfants apprenant des langues diverses. La comparaison entre le babillage et les premiers mots a révélé une continuité entre les deux types de production, mais également une certaine complexification et diversification dans les premiers mots, qu'il est possible d'expliquer par une augmentation des capacités articulatoires.

Mots clés: Babillage, premiers mots, tachelhit, contraintes biomécaniques, continuité

\section{INTRODUCTION}

Contrary to Jakobson's (1968) assertion that there is no relation between babbling and early speech forms, longitudinal investigations of the transition from canonical babbling to speech have shown continuity between the phonetic forms in infant pre-linguistic vocalizations and the earliest speech forms (Oller et al. 1976, Oller 1980, Stark 1980, Locke 1983, Stoel-Gammon and Cooper 1984, Vihman et al. 1985, Vihman et al. 1986) ${ }^{1}$. Babbling is considered as a crucial first step in understanding the nature of the young child's journey toward mastery of ambient language phonology. In addition, comparing canonical babbling patterns with sound patterns in contemporary languages can help in characterizing the basis of phonological patterns in languages. This comparison can potentially highlight common patterns as well as underscore the diversity of language complexity that must be mastered by infants to achieve intelligible message transmission in their ambient language.

\subsection{From babbling to first words}

A consistent developmental trajectory has been proposed to describe early vocalizations in young children. According to a large number of studies (e.g., Zlatin 1975, Oller 1980, Stark 1980, Koopmans-van Beinum and van der Stelt 1986, Roug et al. 1989, Oller et al. 1999, Nathani and Oller 2001), canonical babbling appears around six to eight months of age in typically developing children. It has been defined as rhythmic alternations between consonant and vowel-like properties, giving the appearance of rhythmic speech without conveying meaning (Oller 2000). Two types of canonical babbling have been described: reduplicated babbling, composed of repeated syllables (mamama), and variegated babbling, in which children change vowels and/or consonants in two successive syllables (papi, pada or padi). Earlier views of the period between onset of canonical babbling and first word use were of an initial stage of reduplicated babbling, followed by variegated babbling (Oller 1980, 1986; Stark 1980; Elbers 1982; Roug et al. 1989). Later studies failed to replicate this tendency, instead showing concurrent use of both types with a higher frequency of reduplicated babbling at the beginning of babbling (Smith et al. 1989; Mitchell and Kent 1990; Davis and MacNeilage 1995, 2000). However, this failure to find a developmental shift from reduplicated to variegated

\footnotetext{
${ }^{1}$ Abbreviations used : AP : articulatory phonology ; Bab : babbling ; C/B:coronal/back; C : consonant ; C/F : coronal/front; F/C : Frame-Content ; ID : independence déviation ; LLQ : lower left quadrant ; $\mathrm{V}$ : vowel.
} 
babbling has recently been explained by a masking effect due to the asynchronous appearance of new syllable types. Lipkind et al. (2013) tracked the frequencies of reduplicated transitions in nine children learning American English from nine to 28 months, aligning the data in reference to the age where the speech/babbling ratio reached $50 \%$. They did not observe any changes in the use of reduplicated syllables with age. In a second step, they calculated the same measure, this time aligning the data in reference to the time of appearance of each syllable type. They found a clear shift from high to low reduplication frequency, occurring over 20-30 weeks from time of appearance: syllables tended to be reduplicated when first acquired, before a gradual transition to variegation.

First words are typically produced around the first birthday (Fenson et al. 1993) and words and babble coexist for several months thereafter.

\subsection{Children's preferences in babbling and first words}

Strong similarities in sound and syllable types, and intrasyllabic and intersyllabic preferences in canonical babbling and first words across different language communities have been documented. These preferences have suggested a potentially universal basis for perceptually apparent speech-sound types emerging from infant production system capacities. In this article, we will consider similarities in consonants, vowels, syllable types, and intrasyllabic association.

\subsubsection{Consonants in babbling and first words}

For consonants, in babbling and first words of children acquiring several different languages, oral $[\mathrm{b}, \mathrm{p}]$ or nasal labial stops [m], oral [t, d] or nasal [n] coronal stops and to a lesser extent glides [w, j] (see Table 1 below) are the most preferred sounds. Based on available studies, children from different ambient language backgrounds appear to most frequently produce consonants with a complete closure in the front part of the vocal tract.

These preferences are not shared by all children in their first words, as is particularly evident in children acquiring different varieties of Arabic. Rosenhouse (2000) observed an important use of velars, uvulars, pharyngeals and glottals in children acquiring Arabic spoken in Israel before the age of 24 months. In certain cases, the use of fricatives has been reported in children's first words: in children learning Egyptian Arabic (Omar 1973), Jordanian Arabic (Amayreh and Dyson 2000), and Arabic spoken in Israel (Rosenhouse 2000), as well as in children learning Mandarin Chinese (Zhu and Dodd 2000). The glottal fricative [h] is often used by children in all these languages as well as in English (Ingram 1981, Locke 1983, Stoel-Gammon 1985, Roug et al. 1989) and Korean (Lee 2003). Finally, children learning Mandarin Chinese (Zhu and Dodd 2000, Chen and Kent 2010) or Quiche (Pye et al. 1987) use many affricates in their words before two years of age.

\subsubsection{Vowels in babbling and first words}

Children also exhibit vocalic sound type preferences in babbling and first words. Their productions have been reported as most often composed of vowels from the 


\begin{tabular}{ll}
\hline \hline Language & Babbling \\
\hline American English & $\begin{array}{l}\text { Kent and Bauer (1985), Stoel-Gammon (1985), Vihman et al. (1985), } \\
\text { Robb and Bleile (1994), Davis and MacNeilage (1995), Kern and }\end{array}$ \\
& $\begin{array}{l}\text { Davis (2009) } \\
\text { Grenon et al. (2007) }\end{array}$ \\
Bai & Cissé (2014) \\
Bambara & Grenon et al. (2007) \\
Canadian English & Kern and Davis (2009) \\
Dutch & Gildersleeve-Neumann and Davis (1998) \\
Ecuadorian & Kern and Davis (2009) \\
Quichua & Cissé (2014) \\
French & Lee et al. (2010), Lee and Davis (2010) \\
Fufulde & Chen and Kent (2010) \\
Korean & Grenon et al. (2007) \\
Mandarin & Kern and Davis (2009) \\
Moroccan & Roug et al. (1989) \\
Romanian & Kern and Davis (2009) \\
Swedish & First Words \\
Tunisian & Winitz and Irwin (1958), Locke (1983), Stoel-Gammon (1985), \\
\hline Language & Vihman et al. (1985), Vihman et al. (1986), Roug et al. (1989), Davis \\
\hline American English & et al. (2002) \\
Cissé (2014) \\
Spanishese & Cissé (2014) \\
Furkish & Chen and Kent (2010) \\
Korean & Cataño et al. (2009) \\
\hline \hline &
\end{tabular}

Table 1: List of studies that mention the preferred consonant trend (oral/nasal-labial/ coronal stops) by languages and developmental stages (babbling/first words).

lower left quadrant of the vowel space (Table 2 below). In particular, children produce mid $[\varepsilon] /[e]$ and low front [æ] / [a] and central vowels [ə] in higher numbers.

Some counterexamples to these preferences have been shown in a few studies. De Boysson-Bardies et al. (1989) performed spectral analysis on vowels produced by 10 -month-old children from four linguistic communities. They found that the categories of front-low and mid-central vowels accounted for the vast majority of vowels across languages. However some crosslinguistic differences were shown: more high-front vowels were found for English, and more low-back vowels for Chinese. Concerning Chinese, two back vowels were produced by children early on: /a/ in Mandarin and / $\mathrm{s} /$ in Cantonese (Stokes and Wong 2002, Chen and Kent 2010). In Egyptian Arabic, the high vowels /i/ and /u/ are both acquired before the age of 18 months, and $13.2 \%$ of /i/ have been found in the first words of children 


\begin{tabular}{|c|c|}
\hline Language & Babbling \\
\hline American English & $\begin{array}{l}\text { Chen and Irwin (1946); Buhr (1980); Bickley (1983); Kent and } \\
\text { Bauer (1985); de Boysson-Bardies et al. (1989); Davis and } \\
\text { MacNeilage (1990, 1995); Kern and Davis (2009) }\end{array}$ \\
\hline $\begin{array}{l}\text { American English/ } \\
\text { Serbian }\end{array}$ & Zlatic et al. (1997) \\
\hline Arabic & de Boysson-Bardies et al. (1989), Kern and Davis (2009) \\
\hline Bambara & Cissé (2014) \\
\hline Brazilian Portuguese & Teixeira and Davis (2002) \\
\hline Cantonese Chinese & de Boysson-Bardies et al. (1989), Lee (2006) \\
\hline Dutch & Kern and Davis (2009) \\
\hline Ecuadorian Quichua & Gildersleeve-Neumann and Davis (1998) \\
\hline French & de Boysson-Bardies et al. (1989), Kern and Davis (2009) \\
\hline Fufulde & Cissé (2014) \\
\hline Kannada & Anjana and Sreedevi (2008) \\
\hline Korean & Lee and Davis (2010) \\
\hline Malayalam & Reeny and Sreedevi (2013) \\
\hline Mandarin Chinese & Chen and Kent (2010) \\
\hline Romanian & Kern and Davis (2009) \\
\hline Tunisian & Kern and Davis (2009) \\
\hline Language & First Words \\
\hline American English & $\begin{array}{l}\text { Buhr (1980); Bickley (1983); Davis and MacNeilage (1990, 1995); } \\
\text { Davis et al. (2002) }\end{array}$ \\
\hline Bambara & Cissé (2014) \\
\hline Cantonese Chinese & Stokes and Wong (2002) \\
\hline Korean & Lee $(2003)$ \\
\hline Mandarin Chinese & Chen and Kent (2010) \\
\hline Malayalam & Reeny and Sreedevi (2013) \\
\hline Fufulde & Cissé (2014) \\
\hline
\end{tabular}

Table 2: List of studies which mention the preferred vowel trend (vowels from the lower left quadrant) according to languages and developmental stages (babbling/first words).

learning Jordanian Arabic (Amayreh and Dyson 2000). The vowels /i/ and /u/ made predominant appearance in children six to twelve months of age learning Kannada and Hindi (Shyamala and Devi 2003, Anjana and Sreedevi 2008).

\subsubsection{Syllable types in babbling and first words}

Most represented syllable types in babbling and first words are CVs and C1V1C1V1s (see Table 3). Open syllables are the most-used syllables in children's productions. Closed syllables were found to be very limited in the children's repertoire at these early stages of development.

While most studies support the preferred trend for CV/C1V1C1V1, there are some exceptions. For instance, Fee and Ingram (1982) and Stoel-Gammon and 


\begin{tabular}{|c|c|}
\hline Language & Babbling \\
\hline $\begin{array}{c}\text { American } \\
\text { English }\end{array}$ & $\begin{array}{l}\text { Branigan (1976), Oller (1980), Oller and Eilers (1982), Prater and Swift } \\
\text { (1982), Locke (1983), Kent and Bauer (1985), Stoel-Gammon (1985), } \\
\text { Smith el al. (1989) }\end{array}$ \\
\hline Bambara & Cissé (2014) \\
\hline Fufulde & Cissé (2014) \\
\hline Kannada & Anjana and Sreedevi (2008) \\
\hline Malayalam & Reeny and Sreedevi (2013) \\
\hline Spanish/English & Oller and Eilers (1982) \\
\hline Language & First Words \\
\hline $\begin{array}{l}\text { American } \\
\text { English }\end{array}$ & $\begin{array}{l}\text { Branigan (1976), Prater and Swift (1982), Lahey et al. (1985), Stoel- } \\
\text { Gammon (1985), Smith et al. (1989), Vihman (1992) }\end{array}$ \\
\hline English/Hebrew & Berman $(1977)$ \\
\hline Swedish & Nettelbladt (1982) \\
\hline Spanish & Macken (1978) \\
\hline Urdu & Khan (1984) \\
\hline
\end{tabular}

Table 3: List of studies that mention the preferred syllable type (CV or C1V1C1V1) by languages and developmental stages (babbling/first words).

Cooper (1984) found inter-individual differences among English-learning children in their babbling and first words productions: some had dominant open syllables and some had dominant closed syllables. One Dutch child followed by Elbers and Ton (1985) produced the following types of syllable patterns: $\mathrm{VC}(\mathrm{V}),(\mathrm{V}) \mathrm{CVC}(\mathrm{V})$, with no predominant $\mathrm{CV}$ preference in his first word stage. The same results have been shown in bilingual children. Ingram (1981) found the same inventories in a two-year-old Italian-English child for both languages, but the syllabic patterns were not the same for the two languages. In Italian, the child produced mostly open syllables in multisyllabic utterances, whereas in English, he produced mostly monosyllabic utterances with closed syllables. A very similar result has been showed by Shi (1988) for an English-Chinese bilingual child between 12 and 18 months. In that case, there was no open-syllable preference in English but the child had a dominant CV pattern for Chinese words.

\subsubsection{Consonant-Vowel association in babbling and first words}

In a typical utterance, consonants and vowels do not appear in isolation but are produced serially. Children also exhibit preferences for within-syllable patterns in their prelinguistic babbling vocalizations and in their first words. Three preferred trends have been observed at greater-than-chance levels in children learning different languages: labial consonants + central vowels, coronal consonants + front vowels and dorsal consonants + back vowels (see Table 4).

Some counterexamples to these intrasyllabic CV preferences have been documented in the babbling and first words periods. For the coronal-front association, 


\begin{tabular}{|c|c|c|}
\hline \multicolumn{3}{|c|}{ Labial consonants + central vowels } \\
\hline Language & Babbling & First words \\
\hline $\begin{array}{l}\text { American } \\
\text { English }\end{array}$ & $\begin{array}{l}\text { Davis and MacNeilage (1990), } \\
\text { Vihman (1992), Oller and } \\
\text { Steffans (1993), Kern and Davis } \\
\text { (2009), Giulivi et al. (2011) }\end{array}$ & \\
\hline Bambara & Cissé (2014) & \\
\hline \multicolumn{2}{|c|}{ Brazilian Portuguese } & $\begin{array}{l}\text { Davis and MacNeilage (1990), } \\
\text { Davis et al. (1999) }\end{array}$ \\
\hline Cantonese & Chan (2001) & \\
\hline Dutch & Kern and Davis (2009) & \\
\hline $\begin{array}{l}\text { Ecuadorian } \\
\text { Quichua }\end{array}$ & $\begin{array}{l}\text { Gildersleeve-Neumann et al. } \\
\text { (2013) }\end{array}$ & $\begin{array}{l}\text { Davis \& MacNeilage (1990), Davis } \\
\text { et al. (1999), Gildeersleeve- } \\
\text { Neuman et al. (2013) }\end{array}$ \\
\hline $\begin{array}{l}\text { English/ } \\
\text { Serbian }\end{array}$ & Zlatic et al. (1997) & \\
\hline French & $\begin{array}{l}\text { Vihman (1992), de Boysson- } \\
\text { Bardies (1993), Kern and Davis } \\
\text { (2009), Giulivi et al. (2011) }\end{array}$ & $\begin{array}{l}\text { Vihman (1992), de Boysson- } \\
\text { Bardies (1993) (1 } \text { st }^{\text {st }} \text { sllable), Davis } \\
\text { et al. (1999) }\end{array}$ \\
\hline Fufulde & Cissé (2014) & \\
\hline Italian & & Zmarich and Miotti (1999) \\
\hline Japanese & Vihman (1992) & $\begin{array}{l}\text { Davis and MacNeilage (1990), } \\
\text { Vihman (1992), Davis et al. (1999) }\end{array}$ \\
\hline Korean & Lee et al. (2010) & Lee $(2003)$ \\
\hline Mandarin & $\begin{array}{l}\text { Chen and Kent (2005), Giulivi } \\
\text { et al. (2011) }\end{array}$ & Chen and Kent (2005) \\
\hline Romanian & Kern and Davis (2009) & \\
\hline Swedish & Vihman (1992) & $\begin{array}{l}\text { Davis and MacNeilage (1990), } \\
\text { Vihman (1992), de Boysson- } \\
\left.\text { Bardies (1993) (1 } 1^{\text {st }} \text { syllable }\right)\end{array}$ \\
\hline Turkish & Kern and Davis (2009) & \\
\hline \multicolumn{3}{|c|}{ Coronal consonants + front vowels } \\
\hline Language & Babbling & First words \\
\hline $\begin{array}{l}\text { American } \\
\text { English }\end{array}$ & $\begin{array}{l}\text { Davis and MacNeilage (1990), } \\
\text { Langsdale (1993), Davis et al. } \\
\text { (1999), Kern and Davis (2009) }\end{array}$ & $\begin{array}{l}\text { Fudge (1969), Stoel-Gammon } \\
\text { (1985), Davis and MacNeilage } \\
\text { (1990), de Boysson-Bardies } \\
\text { (1993), Oller and Steffans (1993), } \\
\text { Davis et al. (1999) }\end{array}$ \\
\hline \multicolumn{2}{|c|}{ Brazilian Portuguese } & Davis et al. (1999) \\
\hline Cantonese & Chan (2001) & \\
\hline Czech & & Jakobson (1968) \\
\hline Dutch & $\begin{array}{l}\text { Zink (2005), Kern and Davis } \\
\text { (2009) }\end{array}$ & Levelt (1996) \\
\hline French & Kern and Davis (2009) & $\begin{array}{l}\text { Jakobson (1968), de Boysson- } \\
\text { Bardies (1993), Davis et al. (1999) }\end{array}$ \\
\hline
\end{tabular}


Table 4: (Cont.)

\begin{tabular}{|c|c|c|}
\hline \multicolumn{3}{|c|}{ Labial consonants + central vowels } \\
\hline Language & Babbling & First words \\
\hline Italian & & Zmarich and Miotti (1999) \\
\hline Japanese & & Davis et al. (1999) \\
\hline Korean & Lee et al. (2010) & Lee $(2003)$ \\
\hline Quichua & $\begin{array}{l}\text { Gildersleeve-Neumann et al. } \\
\text { (2013) }\end{array}$ & $\begin{array}{l}\text { Davis et al. (1999), Gildersleeve- } \\
\text { Neumann et al. (2013) }\end{array}$ \\
\hline Mandarin & & Chen and Kent (2005) \\
\hline Romanian & Kern and Davis (2009) & \\
\hline Turkish & Kern and Davis (2009) & \\
\hline \multicolumn{3}{|c|}{ Dorsal consonants + back vowels } \\
\hline Language & Babbling & First words \\
\hline $\begin{array}{c}\text { American } \\
\text { English }\end{array}$ & $\begin{array}{l}\text { Davis and MacNeilage (1990), } \\
\text { Vihman (1992), Oller and } \\
\text { Steffans (1993), Kern and Davis } \\
\text { (2009) }\end{array}$ & $\begin{array}{l}\text { Davis and MacNeilage (1990); } \\
\text { Vihman (1992); Oller and Steffans } \\
\text { (1993); Davis et al. (1999, 2002) }\end{array}$ \\
\hline \multicolumn{2}{|c|}{ Brazilian Portuguese } & Davis et al. (1999) \\
\hline Cantonese & Chan (2001) & \\
\hline Dutch & Kern and Davis (2009) & Levelt (1996) \\
\hline French & $\begin{array}{l}\text { Vihman (1992), Kern and Davis } \\
\text { (2009) }\end{array}$ & $\begin{array}{l}\text { Vihman (1992), de Boysson- } \\
\text { Bardies (1993), Davis et al. (1999) }\end{array}$ \\
\hline Japanese & Vihman (1992) & Vihman (1992), Davis et al. (1999) \\
\hline Korean & Lee et al. (2010) & Lee $(2003)$ \\
\hline Mandarin & Chen and Kent (2005) & Chen and Kent (2005) \\
\hline Quechua & $\begin{array}{l}\text { Gildersleeve-Neumann et al. } \\
\text { (2013) }\end{array}$ & \\
\hline Swedish & Vihman (1992) & Vihman (1992), Davis et al. (1999) \\
\hline Tunisian & Kern and Davis (2009) & \\
\hline Turkish & Kern and Davis (2009) & \\
\hline
\end{tabular}

Table 4: List of studies which mention the three preferred $\mathrm{CV}$ associations according to languages and developmental stages (babbling/first words).

counterexamples are rare. Only Vihman (1992) observed significant individual differences in her data, from the Stanford Child Phonology Project. The majority of children (out of 23 children aged eight to 24 months - eight American English, five Japanese, five French, and five Swedish) followed the preferred trends. Three American English and two Swedish-speaking children did not show a significant association of coronals with front vowels. However, in this study, vowels were categorized differently than in other studies: the vowel/æ/ was considered to be a central vowel whereas in all other studies, /æ/ was considered to be a front vowel; this difference could explain the difference in her results. The second case comes from de 
Boysson-Bardies (1993), who showed that coronal-front association was observed in all children in utterance-initial position, but that in second syllable position, coronals were associated with either central or back vowels in French, Swedish and Yoruba. Finally, Sussman et al. (1996) did not find a preferred trend in a longitudinal single case study of one American English-speaking child from 12 to 21 months: coronals were produced next to a variety of vowels.

Similarly, the labial-central association is not always preferred by children. At least three studies (Fudge 1969, Stoel-Gammon 1985, Langsdale 1993) showed an equal distribution between labial-central vowel and labial-back vowel patterns in English, whereas Sussman et al. (1996) and de Boysson-Bardies (1993) had an equal distribution between labial-central vowel and labial-front vowel associations. The labial-central vowel association is not preferred in other languages such as French (Jakobson 1968), Dutch (Levelt 1996), or Mandarin (Chen and Kent 2005), where children prefer to associate labials to back vowels.

Even more variability is found for the association of vowels with dorsal consonants. In their babbling study of six American English, five French and five Mandarin children at six, nine, and 12 months, Giulivi et al. (2011) did not find a preference for dorsal-back association. Sussman et al. (1996) did not find a preferred trend in a longitudinal single case study of one American-English-speaking child from 12 to 21 months: dorsals were associated with high front and low back vowels, and labials with high front or back vowels. According to de Boysson-Bardies (1993), Langsdale (1993) and Fudge (1969), velar consonants were preferentially associated with central vowels in children acquiring English. Moreover, according to de Boysson-Bardies (1993), velar consonants were associated with central vowels in Swedish-learning children and to front vowels in Yoruba. In Cissé's (2014) babbling data in Bambara and Fufulde, dorsal consonants were associated with central vowels. In one Italian infant (Zmarich and Miotti 1999) the dorsal-back vowel association was not noted in either babbling or first words.

\subsection{From motor constraints to learning from ambient language}

The preferred trends in children's early production have been explained from different perspectives (Jakobson's (1968) theory of universals, and Stampe's (1969) Natural Phonology, among others). Another way to conceptualize the preferred trends is to adopt a biomechanical constraints perspective. MacNeilage and Davis (1990a, 1990b, 1993) have proposed "Frame-Content" (F/C) as a metaphor to describe spatio-temporal and biomechanical characteristics of the babbling and early-speech periods of development. The F/C account posits that the earliest form of speech is the result not of speech per se but of rhythmic mandibular oscillation, what has been called the "Frame". The lips and tongue are hypothesized not to be actively controlled at this stage. "Content" refers to the later phases of acquisition wherein children master the capacity for independent movements of articulators from the jaw cycle when producing strings of syllables. This independent movement results in the ability of young children to program other articulators independently of the jaw. With increasing mastery over accurate placement of independent articulators, 
they begin the process of accurately reproducing diverse ambient language sound types in their early language output.

Browman and Goldstein (1986) as well as Goldstein et al. (2006) in their Articulatory Phonology (AP) provide an alternative model, also physiologically motivated, for the preference for certain types of $\mathrm{CV}$ associations in babbling and first words. They attribute preferences to demands placed on shared articulators: the favoured preferences result from inherent articulatory compatibility, so that coordinated movements to produce the $\mathrm{C}$ and $\mathrm{V}$ constrictions can begin synchronously. $\mathrm{CV}$ preferred associations are those where articulations are either mechanically independent or constricted at the same locations. Both F/C and AP support the preferred patterns, but only the $\mathrm{F} / \mathrm{C}$ model predicts a decrease in these preferred patterns with age, as infants gain articulatory control. Moreover, articulatory synergy is present not only in the three predicted preferred CV patterns, but should also affect other combinations which could also potentially reach an expected-to-observed ratio greater than 1.0 .

These two models have been challenged by a number of counterexamples, as described above. But these counterexamples can partly be explained by methodological limitations and/or differences that make the comparability of results very complicated. In general, studies are limited in the number of participants and/or in data samples for participants, so conclusions must be taken as requiring further confirmation. Another important methodological issue which hinders direct comparison of results across languages and studies lies in the heterogeneity of data collection, transcription and data coding conventions. Oller and Steffans (1993), for example, analyzed expected frequencies of consonants without taking vowels into account, while other studies included both consonant and vowel patterns (e.g., Davis and MacNeilage 1995). In most available research, frequencies of segments or segmental combinations in prelinguistic infant vocalizations are not systematically compared to frequencies in the ambient language. Only few studies, like those of Lee et al. (2008) and Lee and Davis (2010), which compared American English and Korean, have systematically compared infants' speech to the adult input speech directed at infants. Moreover, studies by de Boysson-Bardies et al. (1984) and Weir (1966), which postulated a capacity in naïve adults to correctly identify ambient language by listening to babbling of children from different linguistic communities, have been challenged (see Atkinson et al. 1970, Olney and Scholnick 1976, Thevenin et al. 1985). Some of the counterexamples may also be explained by the influence of ambient-language characteristics. It is generally acknowledged that input from the ambient language plays a role in children's very early perception as early as eight to ten months (Werker and Lalonde 1988). It has also been proposed that learning from input may influence and shape vocalization output preferences in the late babbling and/or first word periods. Researchers have observed the appearance of ambient-language prosodic characteristics in children's prelinguistic utterances (de Boysson-Bardies et al. 1984, Konopczynski 1986, Snow and Stoel-Gammon 1994). In other cases, the appearance of ambient-language influences in production repertoires has been observed in utterance and syllable structures (Levitt and Uttman 1992, de Boysson-Bardies 1993, Kopkalli-Yavuz and Topbaş 2000), in 
vowel and consonant repertoires (de Boysson-Bardies et al. 1984) as well as in CV co-occurrence preferences (Chen and Kent 2005, Lee et al. 2008, Lee and Davis 2010). But until now, these empirical investigations of early ambient-language learning have not been able to provide clear evidence of the appearance and timing of ambient-language patterning in young children's spontaneous output.

\subsection{Goals and hypotheses of the study}

The aim of this article is to evaluate the role of biomechanical constraints on babbling and first words production in two Berber children acquiring Tashlhiyt. First, we examine whether children exhibit preferred forms in their babbling and first words stages. In other words, we aim to verify whether Berber children follow the general preferred trends observed in babbling and first words of children acquiring other languages. If this is the case, we expect to find the following:

- A greater use of oral and nasal stops and glides in comparison to other manners of articulation;

- More labial and coronal consonant places of articulation than other places of articulation;

- More vowels from the lower left quadrant of the vocalic space than other types of vowels;

- More open syllables than closed syllables;

- Three preferred C/V associations: labial consonants + central vowels, coronal consonants + front vowels, dorsal consonants + back vowels.

Second, we compare the production of sounds and sound combinations in babbling and first words, to discover any evidence for a continuity between the two periods. This study will be the first to examine babbling and first words development in Tashlhiyt, a Berber language that presents very peculiar phonetic and phonological characteristics from a developmental perspective.

\subsubsection{Tashlhiyt: a Berber language}

Berber is an Afroasiatic language spoken in large parts of North Africa, mainly in Morocco and Algeria, and to a lesser extent in Mali, Niger, Libya, Egypt, Tunisia and Burkina Faso. Three main varieties are found in Morocco: Tashlhiyt, the variety investigated here, is spoken in Southern Morocco; Tamazight is spoken in the Middle Atlas, and Tarifit is spoken in Northern Morocco. Kabyle is the main variety spoken in Algeria. Tamashek or Touareg is found in Niger, Mali and Southern Algeria (see Chaker 1992).

Tashlhiyt, whose native speakers are estimated at four million (based on data from the official census of 2004$)^{2}$ presents interesting phonetic and phonological features which can serve as a testing ground for important theoretical proposals. Probably the most important feature is the use of complex consonant clusters,

\footnotetext{
${ }^{2}$ This is also mentioned in http://www.ethnologue.com/language/shi. Chaker (1992) refers to three million native speakers at the beginning of the 90s. According to Boukous (2011:28), $28 \%$ of the population speaks Berber (also called Amazigh), of which $52 \%$ are native speakers of Tashlhiyt.
} 
allowing even utterances without any vocalic segment (e.g., ts:kfft:nt 'you faded them (fem.)'). Based on these facts, Dell and Elmedlaoui (1985, 2002) argue that in Tashlhiyt any segment, even a voiceless obstruent, may act as a syllabic nucleus. Another remarkable feature relates to geminates: Tashlhiyt has highly uncommon word-initial geminates along with word-medial and word-final geminates (e.g., $d d u$ 'go', aggu 'smoke', ass 'day').

Tashlhiyt has only three vowels /i, a, u/, two of which are generally analysed as being in complementary distribution with the corresponding glides. That is, any high vowel /i/ or / $\mathrm{u} /$ adjacent to another vowel surfaces as a glide /j/ or /w/ (e.g., kmi 'smoke' / akm:aj 'smoker'; gru 'pick up' / agraw 'assembly'). The phenomenon has been thoroughly documented in Guerssel (1986), Dell and Elemdlaoui (2002) and Lahrouchi (2013), among others. In addition to the three cardinal vowels, Tashlhiyt has also so-called 'transitional vocoids', often referred as to schwa, which appear in certain consonant clusters (e.g., tigammi 'house', agartil 'mat'). According to Dell and Elmedlaoui (2002), these vowels have no syllabic status in the language, while Coleman $(1996,2001)$ suggests that they are actually epenthetic, filling syllabic nuclei that would otherwise remain empty. As to consonants, Tashlhiyt has 33 phonemic consonants and two semi-consonants /j, w/ if one accepts that the later are phonemic. The consonants are listed in Table (5).

Each of these segments has a geminate counterpart. As mentioned earlier, geminates are found in word-medial position as well as in initial and final position. Table 5 also shows phonemic pharyngealized coronals and labialized dorsals, as opposed to their plain counterparts. It also displays a series of dorsal and guttural consonants, which are known to be acquired later than the consonants produced in the front part of the vocal tract. All of these phonological properties will prove interesting in the study of language acquisition. In what follows, we examine how these properties arise during the babbling and first words periods.

\section{METHOD}

In the following sections, we will present data collection design as well as details about the collected corpora.

\subsection{Data collection}

Two Moroccan children acquiring Tashlhiyt Berber language participated in the study: a girl called Imane and a boy called Reda. These data were collected as a part of a longitudinal project on early language acquisition from seven to 24 months of age (Agence Nationale de Recherche: Premiers Mots (PREMS), PI: Sophie Kern). One hour of spontaneous vocalization data was audio and video recorded every two weeks in the children's homes. Parents were told to follow their normal types of activities with their child. No extra objects were introduced into the environment, so that samples reflected the children's typical vocalizations in familiar surroundings. The observer was present and interacted with the parent informally. Family members or guests were occasionally present. A digital audio 


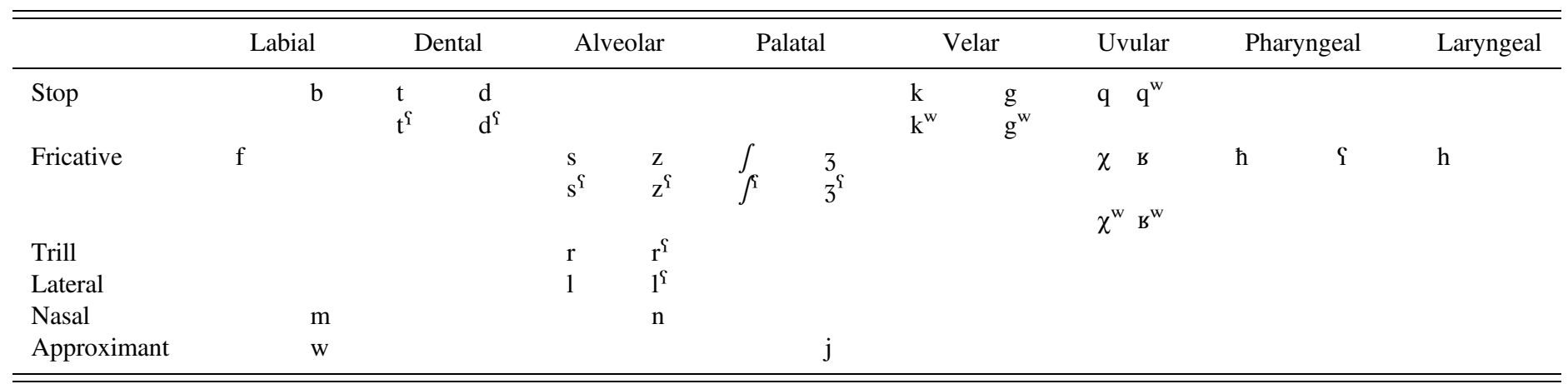

Table 5: The phonological consonant inventory of Tashlhiyt Berber. 
recorder was used for both data collection and subsequent transcription. Each infant wore a wireless microphone in a cloth vest. The microphone was clipped at the shoulder to keep a consistent mouth-to-microphone distance and to discourage the infant from handling the microphone. At the rate of two recording sessions per month, we ended up with 31 sessions of one hour each for Reda and 26 for Imane; the difference being due to the fact that Reda was monitored from the age of seven months while Imane started two months later.

\subsection{Data selection}

To examine potential for change from babbling to first words, collected data was divided into two periods: period 1 (from seven to 12 months), and period 2 (from 13 to 24 months). Both periods include both babbling and word utterances, though the first period is typically characterized by babbling productions while the second period favours words. In this study, only babbling utterances were considered in the first period and only word utterances in the second one. Data selected for analysis included all perceptually rhythmic canonical babbling and first words occurring during each session. Vocalizations analyzed were produced with minimally a consonant-like closure phase (articulatory obstruents, sonorants, and glides), and a vowellike open phase within a single utterance string. This criterion resulted in either $\mathrm{CV}$ or VC monosyllables as minimal units for analysis; polysyllables included $\mathrm{CV}$ or VC alternations. All utterance strings analyzed were comfort state vocalizations produced without background noise. Consonant, vowel, and syllable counts and percentages as well as sequential consonant-vowel association counts and percentages within syllables were produced for each child participant.

\subsubsection{Consonants and vowels}

Consonants were grouped for analysis according to manner of articulation as follows: oral stops, nasal stops, fricatives, liquids, glides and others. The category 'others' was composed of manners of articulation which had a frequency of occurrence under $5 \%$ in both children and both time-periods, that is trills, taps and affricates. Consonants were also grouped according to place of articulation: labials, coronals, dorsals and gutturals. Glides were considered as consonants, as they share the consonantal property of accompanying the mouth-closing phase of babbling. The glide [w] was classified as labial because the paucity of high back vowels in babbling suggests that the usual dorsal component of this glide is probably not prominent. The palatal glide [j] was classified as coronal.

Vowels were grouped for analysis according to backness - front, central and back - and height - high (high and lowered-high), mid (higher-mid, mid and lower-mid) and low (raised-low and low).

\subsubsection{Syllables}

Open and closed syllables are distinguished, regardless of the weight of the margin positions (i.e., onset and coda). This is all the more tenable since no phonological argument has been made in the literature calling for a distinction in Berber 
between heavy and light syllables, except for poetry (see Dell and Elemdlaoui 2002) which may be argued to rely on different rules than everyday speech. The situation becomes even more complex when dealing with consonant clusters, which tend to appear later in children's productions. In this case, it is necessary to implement an explicit theoretical approach to syllable structure accounting for all types of syllables in Tashlhiyt Berber. For the purpose of our analysis, we will be adopting the hypothesis that any segment, even a voiceless obstruent, can appear in the nucleus position. The data is processed by means of a set of syllabic constraints based on Dell and Elmedlaoui's (2002) model of syllabification. The version adopted here involves the rules as advocated by Dell and Elmedlaoui, some of which have been slightly changed. They are listed below.

Two principles:

- The licit consonantal nuclei thesis, which states that any segment - even a voiceless obstruent - can act as a syllabic nucleus.

- The sonority-driven syllabification thesis, which holds that in the competition for the status of syllabic nucleus, more sonorous segments are favoured over less sonorous segments.

To do this, segments are ranked along the following scale, where segments appear in order of decreasing sonority: $\mathrm{a}>$ high vocoids $>$ liquids $>$ nasals $>$ fricatives $>$ stops (see Dell and Elmedlaoui 2002: 76).

Six constraints:

- Complex onsets are prohibited (Dell and Elmedlaoui 2002: 114). This constraint has been slightly modified here, such that only domain-initial onsets can be complex.

- Any rime contains at most three consonants. If so, the last consonants form a geminate (Dell and Elmedlaoui 2002: 98).

- The coda position cannot be more sonorous than the nucleus (Dell and Elmedlaoui 2002: 102).

- Every syllable has an onset, except domain-initially where the onset may be empty (Dell and Elmedlaoui 2002: 92).

- Any sequence with a sonority peak must contain a nucleus (Dell and Elmedlaoui 2002: 100).

- A geminate cannot branch into an onset followed by a nucleus (Dell and Elmedlaoui 2002: 102). However, in cases where none of the above constraints leads to the appropriate syllabification, such as in words made of one geminate (e.g., $k k$ 'go through') as well as in domain-initial position (e.g., $\iint t n t$ 'eat them (fem.)'), the geminate seems to constitute an onset-nucleus sequence, inevitably running counter to Dell and Elmedlaoui's proposal.

\subsection{Data Transcription}

Fifty hours of spontaneous data were broadly transcribed using the 1999 International Phonetic Alphabet system of notation by a native language transcriber who was familiar with transcription of young children's vocalizations. Tokens considered as single utterance strings were separated by one second of silence, noise or adult speech. All singleton consonants and vowels as well as perceptually rhythmic 
syllable-like vocalizations were transcribed. Transcribed data was entered into Phon software (Rose et al. 2006) for the analysis of patterns for the dimensions noted above.

\subsection{Data analysis}

Chi-square tests of independence were used to evaluate the statistical significance of our results. First, this allowed us to test whether the distribution of a variable in a sample was approximately equal in each cell. For instance, we used it to compare the use of different manners of articulation.

Second, the Chi-square test of independence was used to test independence between two variables. In other words, it tested whether or not a statistically significant relationship existed between two variables. In our work, we used the Chi-square test to verify whether specific consonant places of articulation (labial, coronal, dorsal, guttural) were preferentially combined with specific vowel types (front, central, back).

In both cases, the Chi-square test of independence allowed us to compare the observed values of a series of coded categories and the values that would be expected if all categories were randomly distributed in the data. In very few cases, where the expected cell size was below five, we used the Fisher exact test, which can be used on small samples (which is not possible with the Chi-square test of independence). Chisquare or Fisher test results with a p value below 0.05 were considered to be significant.

To know more about the weight of each category on the result, we calculated the deviation from independence for each category. A category that had a high positive deviation from independence was considered to be overrepresented in relation to the reference distribution which would have been obtained if the choice of category had been made randomly. A category that received a high negative deviation was considered to be underrepresented.

\section{RESUlts}

In the next sections, we present the main results. We begin with the main characteristics of the data before turning to the results for isolated segments (consonants and vowels). Finally, the $\mathrm{CV}$ combinations will be explored.

\subsection{Main characteristics of the data}

Table 6 displays a few global characteristics of the analyzed data. It gives number of sessions, number of utterances, consonants, vowels, and syllables, and the $\mathrm{C} / \mathrm{V}$ ratio in both babbling (Bab) and words (Word). Reda was much more talkative than Imane: the number of utterances, consonants and vowels for Reda exceeded those produced by Imane. Only the number of syllables produced by Imane in the word period exceeded Reda's syllable number. Another difference concerns the $\mathrm{C} / \mathrm{V}$ ratio: Imane obtained a $\mathrm{C} / \mathrm{V}$ ratio over one, whereas Reda's $\mathrm{C} / \mathrm{V}$ ratio was close 


\begin{tabular}{|c|c|c|c|c|c|c|c|c|c|c|c|c|}
\hline & \multicolumn{2}{|c|}{ Sessions } & \multicolumn{2}{|c|}{ Utterances } & \multicolumn{2}{|c|}{ Consonants } & \multicolumn{2}{|c|}{ Vowels } & \multicolumn{2}{|c|}{$\mathrm{C} / \mathrm{V}$ ratio } & \multicolumn{2}{|c|}{ Syllables } \\
\hline & $\mathrm{Bab}$ & Word & $\mathrm{Bab}$ & Word & $\mathrm{Bab}$ & Word & $\mathrm{Bab}$ & Word & $\mathrm{Bab}$ & Word & $\mathrm{Bab}$ & Word \\
\hline Imane & 7 & 18 & 157 & 1853 & 528 & 2658 & 505 & 2121 & 1.05 & 1.22 & 348 & 2407 \\
\hline Reda & 7 & 18 & 907 & 2079 & 2051 & 3406 & 2072 & 3523 & 0.98 & 0.96 & 1722 & 1959 \\
\hline Total & 14 & 36 & 1064 & 3932 & 2579 & 6064 & 2577 & 5644 & 1.00 & 1.07 & 2070 & 4366 \\
\hline
\end{tabular}

Table 6: Main characteristics of analyzed data 
but still lower than one. Moreover, Imane's $\mathrm{C} / \mathrm{V}$ ratio was higher in babbling than in words.

\subsection{Consonant manner of articulation}

Oral and nasal stops as well as glides, as opposed to other manners of articulation, have been crosslinguistically described as appearing early in children's productions. As shown in Figure 1, these early-appearing sounds had the highest percentage of occurrence in both children, and in both babbling and words. Oral and nasal stops combined with glides represented $87.55 \%$ and $56.48 \%$ of all consonants in Imane's babbling and first words, and $84.55 \%$ and $72.02 \%$ in Reda's case. Sounds crosslinguistically considered to be acquired late (i.e., fricatives and liquids) were less represented in both children's repertoire (both in babbling and in first words). Figure 1 also shows a smaller difference between the two categories in the word period than in the babbling period, indicating an increase in fricatives and liquids for both children in the second period.

The Chi-square test of Independence confirmed a non-random use of different manners of articulation for both periods and participants (Reda Bab: $\chi^{2}=551.21$, $\mathrm{df}=1, \mathrm{p}=0.0001$, Reda Word: $\chi^{2}=329.75, \mathrm{df}=1, \mathrm{p}=0.0001$; Imane Bab: $\chi^{2}=$ 167, $\mathrm{df}=1, \mathrm{p}<0.001$; Imane Word: $\left.\chi^{2}=51, \mathrm{df}=1, \mathrm{p}<0.001\right)$. The analysis showed a clear overrepresentation of the first group (oral/nasal stops + glides) over the second one (fricatives + liquids) in both babbling and words for both children. Even without the grouping in two larger categories (see Figure 2 below), the results were statistically significant for both periods and children (Reda Bab: $\chi^{2}=$ 710.26, $\mathrm{df}=5, \mathrm{p}=0.00000$, Reda Word: $\chi^{2}=815,98 \mathrm{df}=5, \mathrm{p}=0.000000$; Imane Bab $\chi^{2}=297, \mathrm{df}=5, \mathrm{p}<0.001$; Imane Word: $\left.\chi^{2}=542, \mathrm{df}=2, \mathrm{p}<0.001\right)$.

In babbling, Reda showed a clear overrepresentation of stops (Independence deviation of 593.17) of nasals (ID =104.17) and to a lesser extend of glides

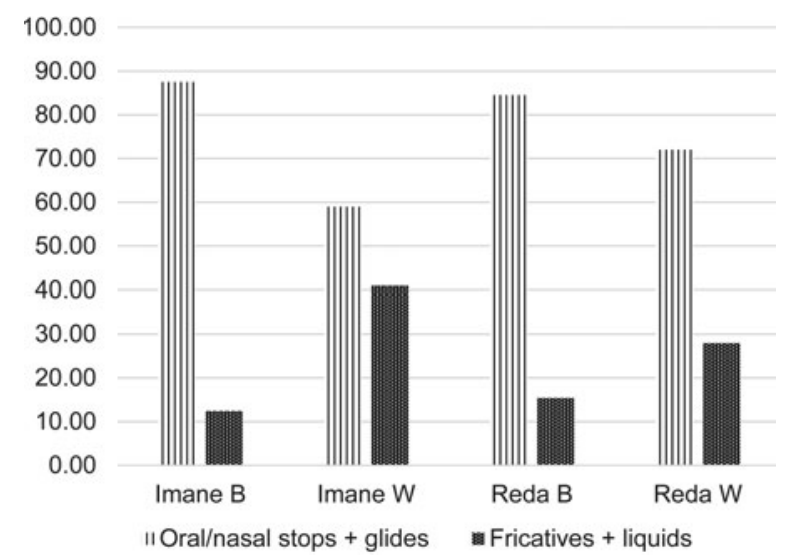

Figure 1: Consonant manner of articulation in both children and production type (babbling and words) 

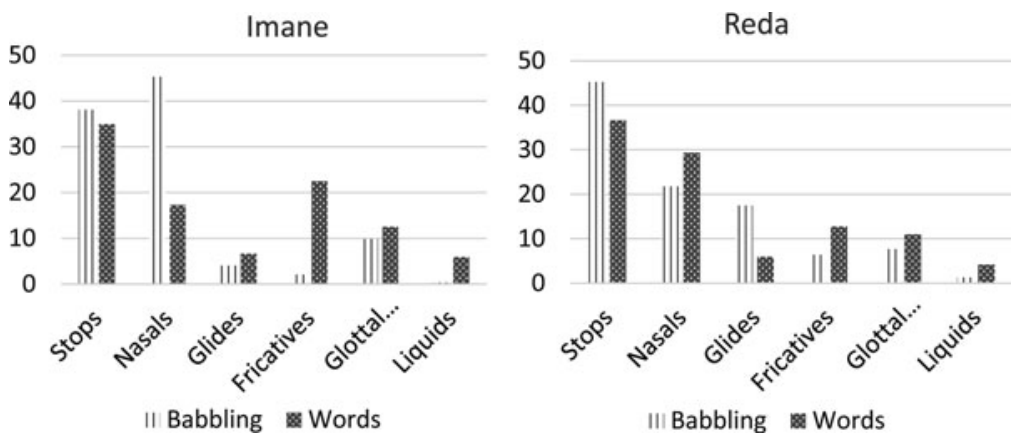

Figure 2: Consonant manners of articulation, Imane and Reda

(ID = 17.17). On the other hand, fricatives, glottal fricatives and liquids were underrepresented (ID of $-208.93,-182.83$ and -312.83 respectively). In Reda's word period, oral stops and nasal stops were even more overrepresented (649.17 and 412.17). Whereas the glides were overrepresented in the babbling period, they are among the least represented categories in the word period $(-346.83$ for glides and -403.83 for liquids), while fricatives have roughly the same underrepresentation in the word period as in the babbling period.

Imane's productions differ in several respects from Reda's productions. Stops and nasals were overrepresented in both children's babbling, but Imane used twice as many nasals as Reda ( $45 \%$ vs. $22 \%$ ). Another difference in babbling is the use of glides, with Imane using one-third as many glides as the other child (4\% vs $17.5 \%$ ). In words, the trend is reversed for nasals, with Reda's repertoire including $29 \%$ nasals (vs. only $16.5 \%$ in Imane's repertoire). A final noticeable difference concerns the number of fricatives (note that the glottal fricatives are considered separately) with Imane's percentage being twice as high as Reda's (12.7\% vs. 25.2\%).

\subsection{Consonant place of articulation}

Both children preferred to use labial and coronal consonants over dorsals and gutturals in both the babbling and word periods. Among all consonants found over the entire period of analysis, between 70 and $80 \%$ are labials and coronals followed by gutturals (from 12 to $20 \%$ in both children) and dorsals (less than $10 \%$ in both children), as presented in Figure 3.

In addition, the data showed that taken together, the percentage of occurrence of labials and coronals decreased by $10 \%$ from Bab (80\%) to Word (70\%) whereas gutturals and dorsals grouped together exhibited the reverse pattern (18\% and 28\%). Figure 3 clearly indicates as well that Imane and Reda differed in their use of labials and coronals only in babbling, with approximately twice as many labials as coronals in Imane's production and the reverse in Reda's production. This reflects the fact that coronals went from being slightly underrepresented in Imane's babbling $(-11)$ to being clearly overrepresented in Imane's first words (617.25). 

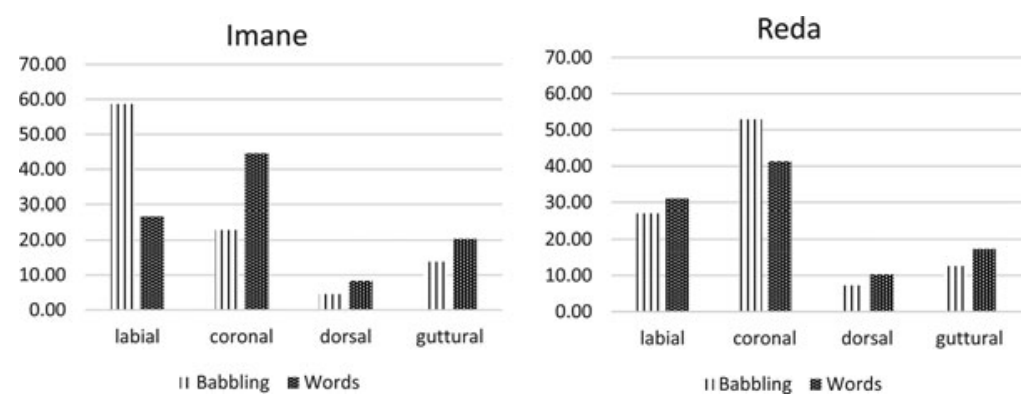

Figure 3: Consonant place of articulation in both children and production type (babbling and words)

The Chi-square test of independence confirmed an uneven representation of all four categories (Reda Bab: $\chi^{2}=490.75$, df $=3, \mathrm{p}=0.000000$, Reda Word: $\chi^{2}=$ 384.06, df $=3, \mathrm{p}=0.000000$; Imane Bab: $\chi^{2}=164$, df $=3, \mathrm{p}<0.001$; Imane Word: $\chi^{2}=454, \mathrm{df}=3, \mathrm{p}<0.001$ ) with a significant overrepresentation of labials (Reda Bab: ID = 44.25; Reda Word: ID = 193.25; Imane Bab: ID = 178; Imane Word: ID = 56.25) and coronals (Reda Bab: ID = 573.25; Reda Word: ID = 525.25; Imane Bab: ID $=-11$; Imane Word: $\mathrm{ID}=617.25$ ) in both periods and children with the exception of Imane's babbling, in which coronals were slightly underrepresented (ID =-11). Dorsal (Reda Bab: ID =-363.75; Reda Word: ID =-467.75; Imane Bab: ID $=-108$; Imane Word: $\mathrm{ID}=-525.75$ ) and guttural (Reda Bab: $\mathrm{ID}=-253.75$; Reda Word: ID $=-250.75$; Imane Word: ID $=-59$; Imane Word: ID $=-147.75$ ) manners of articulation were clearly underrepresented in both children and periods of investigations.

\subsection{Vowel types}

For vowel analysis, we first combined the vowels from the lower left quadrant of vocalic space (LLQ) as this group of vowels are crosslinguistically the first to be used by children. We then compared their frequency of occurrence to that of other vowel types. Figure 4 shows clearly that both children preferred LLQ vowels to other vowels in both babbling and words. This preference is confirmed by the Chi-square test of independence for both children and time-periods (Reda Bab: $\chi^{2}=644.46, \mathrm{df}=1 \mathrm{p}=0.000000 ;$ Reda Word: $\chi^{2}=56.85$, df $=1, \mathrm{p}=0.000000$; Imane Bab: $\chi^{2}=231, \mathrm{df}=1, \mathrm{p}<0.001$; Imane Word: $\chi^{2}=231, \mathrm{df}=1, \mathrm{p}<0.001$ ).

This figure also clearly indicates a decrease in the percentages of LLQ vowels from period 1 to period 2, whereas the other vowel types show an increase. The ratio of LLQ vowels in Reda's productions decreased from 1.73 to 1.18 and from 1.87 to 1.31 in Imane's productions during the observed periods.

A second step in the analysis was to consider vowel use according to backness (Figure 5). Chi-square tests of independence were statistically significant for both periods and children (Reda Bab: $\chi^{2}=1798.16$, $\mathrm{df}=2 \mathrm{p}=0.000000$; Reda Word: $\chi^{2}=833.69$, df $=2, p=0.000000$; Imane Bab: $\chi^{2}=332$, df $=2, p<0.001$; Imane 


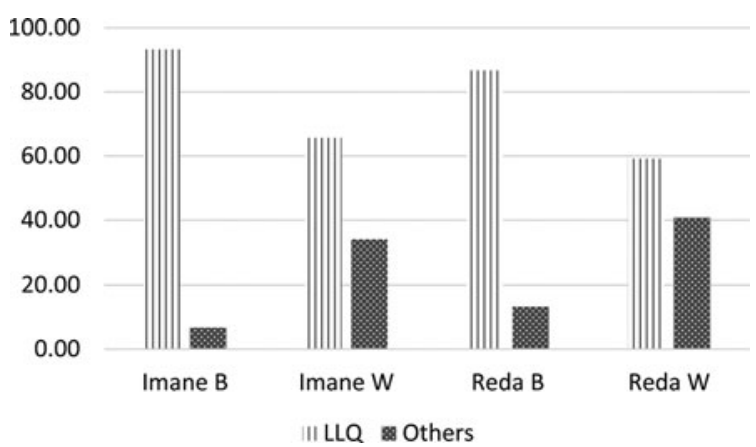

Figure 4: Vowel types (LLQ vs. others) in both children and production type (babbling and words)

Word: $\left.\chi^{2}=455, \mathrm{df}=2, \mathrm{p}<0.001\right)$. Percentages of use for back vowels were very low (under 5\%) in the babbling data but represented around $20 \%$ in the first words data. In babbling, back vowels were clearly underrepresented for both children (Reda ID = -663.67, Imane ID $=-156.33)$. The underrepresentation was still present in Imane's word productions (ID $=-455.67$ ) whereas back vowels were overrepresented in Redas' word productions (ID = 486.67). The children exhibited a very different profile for front and central vowels: Reda used in both periods a very high percentage of front vowels, and less than $5 \%$ of central ones, in both periods, whereas Imane did the reverse. Front vowels were overrepresented in Reda's productions (Reda Bab: ID = 1303.33, Reda Word: ID =1109) and underrepresented in Imane's productions (Imane Bab: ID $=-122.33$, Imane Word: ID = -296.67). In both cases, the most heavily represented category in babbling (front vowels for Reda and central vowels for Imane) decreased in words.

A third step in the study of vowels was to observe their use by height (Figure 6). Here again Chi-square tests of independence were statistically significant for both time periods and children (Reda Bab: $\chi^{2}=1283.17$, df $=2, \mathrm{p}=0.000000$; Reda Word: $\chi^{2}=1226.80, \mathrm{df}=2, \mathrm{p}=0.000000$; Imane Bab: $\chi^{2}=323$, df $=2, \mathrm{p}<0.001$; Imane Word: $\left.\chi^{2}=854, \mathrm{df}=2, \mathrm{p}<0.001\right)$. With respect to vowel height, Reda and Imane were behaving globally the same way: they both used more low vowels than high vowels, which in turn were used less than mid vowels. Independence
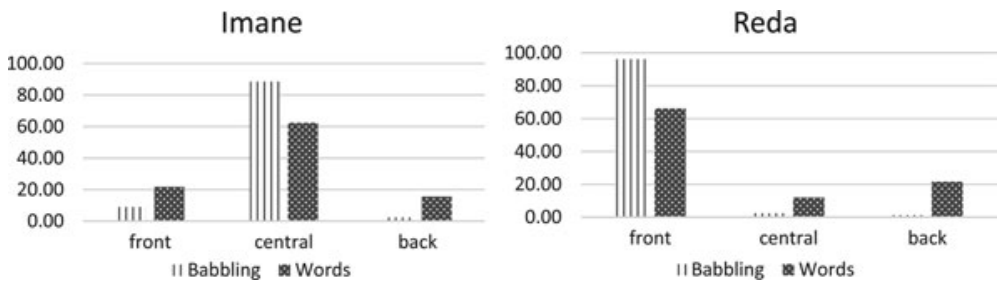

Figure 5: Vowel backness in both children and production type (babbling and words) 

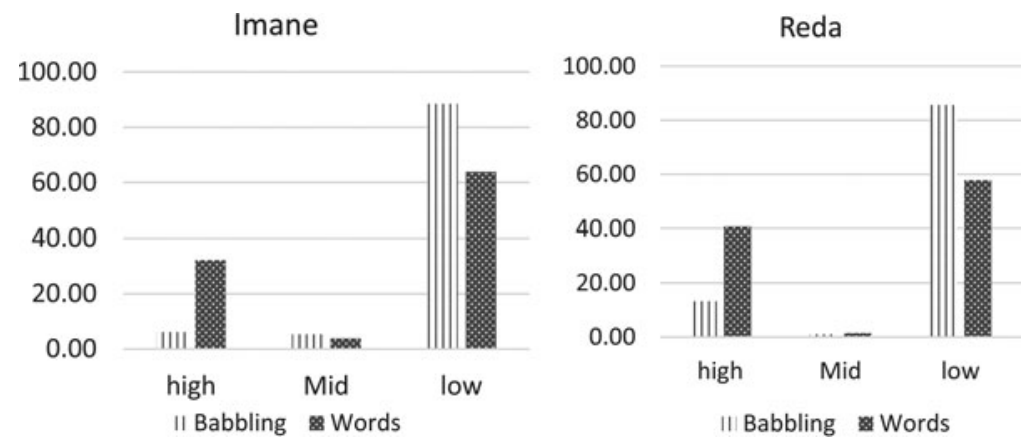

Figure 6: Vowel height in both children and production type (babbling and words)

deviation calculations showed that in babbling, high vowels (Reda Bab: $\mathrm{ID}=-415.67$, Imane $\mathrm{Bab}: \mathrm{ID}=-137.33$ ) and mid vowels (Reda $\mathrm{Bab}: \mathrm{ID}=$ -668.67, Imane $\mathrm{Bab}: \mathrm{ID}=-141.33$ ) were underrepresented, while low vowels were overrepresented (Reda Bab: ID $=1084.33$, Imane Bab: $I D=278.67)$. In the word stage, the same pattern is found in Imane's productions (high vowels ID = -28.67 , mid vowels ID $=-761.67$, and low vowels $\mathrm{ID}=790.33$ ) but not in Reda's productions, where high vowels were overrepresented (high vowels ID $=247$ ).

The changes between babbling and words were also the same for both children, with an increase in high vowels and a decrease in low vowels from babbling to words.

Finally, we examined the individual vowels used by the children in both periods in more detail. Tashlhiyt Berber has only three phonemic vowels, two of which are high closed vowels $/ \mathrm{i}, \mathrm{u} /$, generally considered to be acquired later than the open vowel /a/. Given this phonological property, /a/ is expected to be more frequent in the children's productions than the two closed vowels. Figure 7 gives the percentages of use of specific vowels in both periods by both children.

Children's babbling production involved the three corner vowels that form the vocalic system of Tashlhiyt Berber. Reda mainly used the low front vowel [æ],

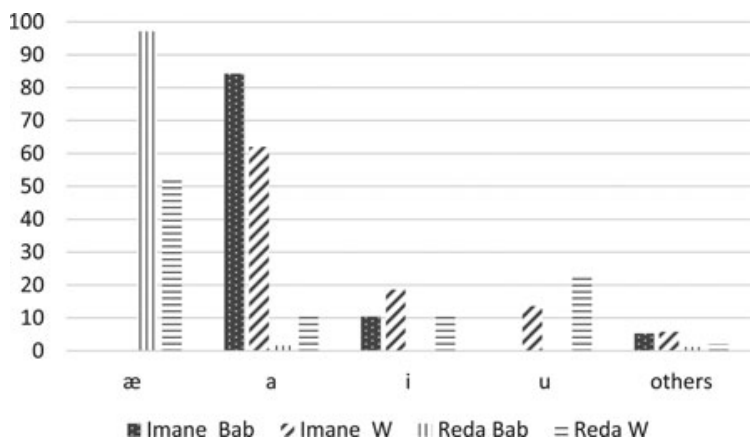

Figure 7: Vowels distribution in both children and production type (babbling and words) 
which accounted for $97 \%$ of of his vowels. Imane's vowels were more diverse, though [a] accounted for $84.5 \%$. Two other vowels were used, albeit less frequently: $10.5 \%$ were [i] and $5 \%$ were [ $\varepsilon$ ]. For vowels produced in the first words period, $62 \%$ of Imane's productions were [a] while Reda preferred the front [æ] (51.7\%). Imane's first words also included instances of the back low [a], which did not exceed $2 \%$ on average. Of interest is the decreasing frequency of [a] in Imane's productions, dropping from $84 \%$ to $62 \%$. In the words period, Reda's preference for [æ] fell from $97 \%$ to $51 \%$. Moreover, Reda started to use the high vowels [i] and [u], with a mean percentage of $23.5 \%$ for [u] and $11 \%$ for [i], and significantly increased his use of [a] $(11 \%)$. Imane's first words included $10 \%$ of mid vowels [e] and $[\varepsilon]$ and very few occurrences of schwa, as opposed to Reda, $2.53 \%$ of whose vowels were schwa while no mid vowels were reported.

Of particular interest is the status of the vowel /a/: not only does it represent about $80 \%$ of the vowels found in babbling, but it also occurred mostly as a low front [æ], specifically in Reda's productions. This is not at all unexpected from a developmental perspective and in adult languages as well. Cross-linguistically, it has been shown that the phonetic space occupied by each vowel depends on the number of vowels a language contains, and that languages with small vocalic systems are therefore more likely to exhibit variation in vowel quality than languages with larger systems (Lindblom 1986, Al-Tamimi and Ferragne 2005). Tashlhiyt Berber is such a language, given the fact that it has only three vowels. Studies in language acquisition further corroborate the variation in the phonetic value of the low central vowel: infants acquiring Tunisian Arabic, whose vowel system is similar to that of Tashlhiyt Berber, have been reported to use the front [æ] much more than the central variant [a] (see Kern and Davis 2009). In our data, this phonetic feature is not the only inter-individual difference: Figure 5 further shows that Imane had mid vowels in her vocalic inventory, especially the front mid [e], which occurred as early as nine months and represented $23 \%$ of all vowels in babbling. However, both children produced a few instances of schwa, which deserve to be examined given their controversial status in Tashlhiyt Berber.

\subsection{Syllable types}

During the babbling period, Imane produced 348 syllables, $82 \%$ of which were open, while Reda had 2175 open syllables, out of 2902 in total (90\%). In the second period, Imane produced 1830 syllables, of which 1560 (85\%) were open, whereas Reda produced 2406, 75\% of which were open. These results are presented in Figure 8.

For both children and both time-periods, open syllables were significantly more common, as confirmed by the statistical analyses (Reda Bab: $\chi^{2}=677.49, \mathrm{df}=1$, $\mathrm{p}=0.000000$; Reda Word: $\chi^{2}=704.55, \mathrm{df}=1, \mathrm{p}=0.000000$; Imane Bab: $\chi^{2}=79$, $\mathrm{df}=1, \mathrm{p}<0.001 ;$ Imane Word: $\chi^{2}=606, \mathrm{df}=1, \mathrm{p}<0.001$ ).

Following the syllabic algorithm adopted here (see section 2.2), 10 syllabic patterns arose in the data: $\mathrm{CV}, \mathrm{V}, \mathrm{CCV}, \underline{\mathrm{C}}, \mathrm{CC}, \mathrm{VC}, \mathrm{CVC}, \mathrm{VCC}, \underline{\mathrm{CC}}, \mathrm{CCC}$ where $\underline{\mathrm{C}}$ represents a syllabic consonant. We included in the analysis all open syllable types that represented at least $5 \%$ of the data. We ended up with four categories: $\mathrm{CV}, \mathrm{V}$, 


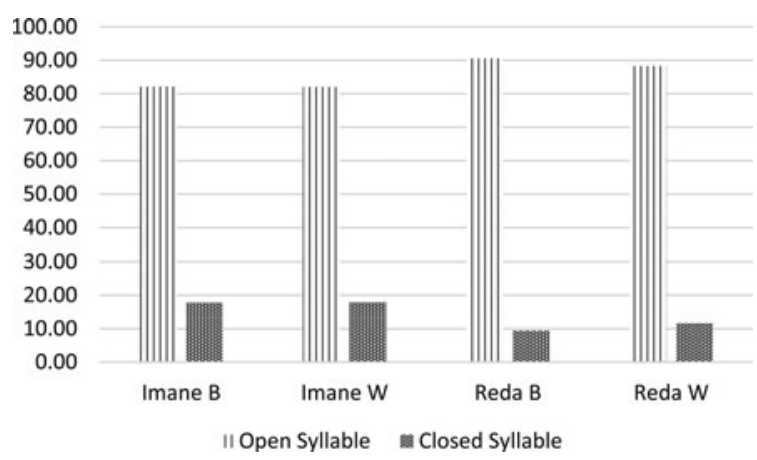

Figure 8: Open vs. Closed syllables in both children and production type (babbling and words)

$\mathrm{CCV}$ and C. Figure 9 shows the proportion of each of these four open syllable types in both children's production.

The open syllable CV was the most commonly used syllable type in both children and production types, followed by the $\mathrm{V}$ type open syllable. The other types were rarely used by the children in either babbling or words. Chi-square analyses showed highly significant results (Reda Bab: $\chi^{2}=942.79$, df $=3, \mathrm{p}=0.000000$; Reda Word: $\chi^{2}=1333.24, \mathrm{df}=1, \mathrm{p}=0.000000$; Imane Bab: $\chi^{2}=253, \mathrm{df}=3$, $\mathrm{p}<0.001$; Imane Word: $\chi^{2}=1871, \mathrm{df}=3, \mathrm{p}<0.001$ ). In three cases (Reda's babbling and words as well as Imane's words), CV syllables were overrepresented, whereas the three other types were all underrepresented. In Imane's babbling, V type was also an overrepresented category, but to a lesser extent (V type ID $=704.25$ vs. CV type ID = 10.25).

As far as closed syllable types were concerned, the children used predominantly CVC and VC types (Figure 10).

Among closed syllables, CVC was the most preferred type, showing a relatively high percentage, particularly in Imane's productions. This pattern was present in
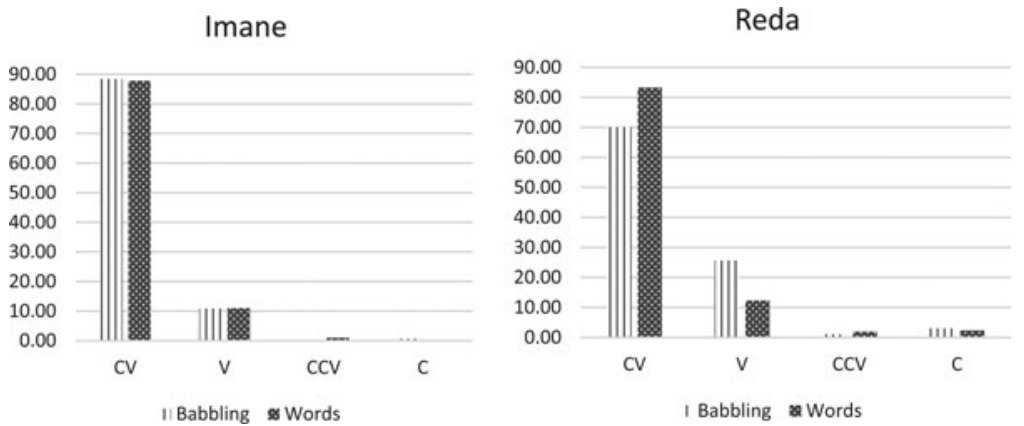

Figure 9: Distribution of open syllables in both children and production type (babbling and words) 


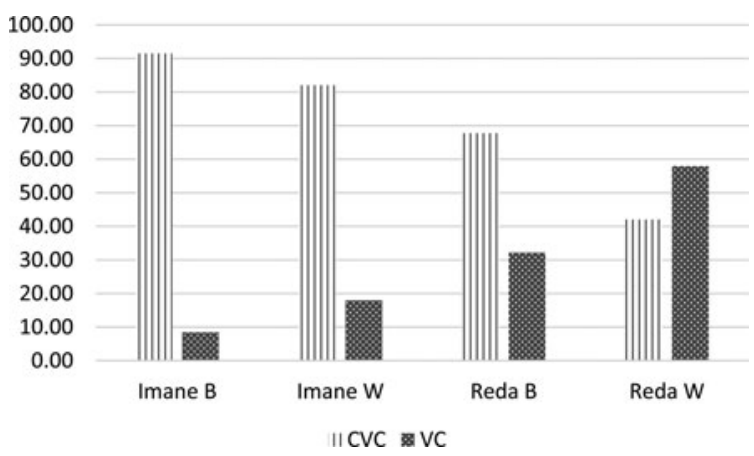

Figure 10: Distribution of closed syllables in both children and production type (babbling and words)

Reda's babbling $\left(\chi^{2}=14.88, \mathrm{df}=1, \mathrm{p}=0.00011\right)$, Imane's babbling $\left(\chi^{2}=22.621\right.$, $\mathrm{df}=1, \mathrm{p}<0.001)$ and Imane's words $\left(\chi^{2}=131.033, \mathrm{df}=1, \mathrm{p}<0.001\right)$. Only Reda's words differed from the preferred pattern, with statistically more VC types than CVC types (Reda Word: $\chi^{2}=6.88, \mathrm{df}=1, \mathrm{p}=0.00869$ ). This suggests an effect of the frequency of geminates in babbling as well as in first words, which, according to the syllabic model used here, are ambisyllabic - typically branching into coda and onset positions - thus resulting in closed syllables.

Very few syllabic patterns other than those shown in the last two figures are found in our data. They include, among other types, CCVC and CVCC syllables, which barely exceeded $1 \%$ of syllables in either babbling or first words. Syllable types containing syllabic consonants do not exceed $4 \%$ in babbling or first words.

\subsection{Intrasyllabic association according to age and production type (babbling and words)}

The final analysis looks at the intrasyllabic CV associations in babbling and words. Table 7 and Table 8 present respectively Imane's and Reda's results for both production types (babbling and words). Ratios of observed to expected frequencies for the nine $\mathrm{CV}$ combinations were generated for each subject at each stage. A value of 1.00 denotes chance occurrence. Values greater than 1.00 indicate $\mathrm{CV}$ pairings occurring at above-chance levels. The numbers in boldface correspond to the ratios of observed to expected frequencies for the three types of $\mathrm{CV}$ combinations predicted as favoured by the F/C and AP accounts, namely labial-central, coronal-front and dorsal-back.

In Imane's production, 12 of 24 possible combinations had a ratio greater than 1. Labials were significantly more associated with central vowels in babbling and words (Bab: ratio $=1.08$, Fisher exact test: $p=0.04$; Word: ratio $=1.2, \chi^{2}=25$, $\mathrm{df}=2, \mathrm{p}=0.01)$. Coronals were statistically more frequently associated to front vowels (Bab: ratio $=3.14$, Fisher exact test: $\mathrm{p}=0.000052$; Word: ratio $=1.46, \chi^{2}=$ $33, \mathrm{df}=2, \mathrm{p}<0.001)$ and, to a lesser extent, to back vowels $(\mathrm{Bab}:$ ratio $=1.22$, Word: ratio $=1.02$ ). In babbling, dorsals were only associated with central vowels, whereas as in words, dorsal + front and dorsal + back ratios were greater than 1 


\begin{tabular}{|c|c|c|c|c|c|c|c|c|}
\hline & \multicolumn{2}{|c|}{ Labial } & \multicolumn{2}{|c|}{ Coronal } & \multicolumn{2}{|c|}{ Dorsal } & \multicolumn{2}{|c|}{ Guttural } \\
\hline & Babbling & Words & Babbling & Words & Babbling & Words & Babbling & Words \\
\hline Front & 0.53 & 0.80 & 3.14 & 1.46 & 0 & 1.37 & 0 & 0.26 \\
\hline Central & 1.08 & 1.12 & 0.75 & 0.82 & 1.15 & 0.73 & 0.92 & 1.28 \\
\hline Back & 0.13 & 0.84 & 1.22 & 1.02 & 0 & 1.17 & 7 & 1.01 \\
\hline
\end{tabular}

Table 7: Ratios of observed to expected frequencies in Imane's babbling and first words

\begin{tabular}{|c|c|c|c|c|c|c|c|c|}
\hline & \multicolumn{2}{|c|}{ Labial } & \multicolumn{2}{|c|}{ Coronal } & \multicolumn{2}{|c|}{ Dorsal } & \multicolumn{2}{|c|}{ Guttural } \\
\hline & Babbling & Words & Babbling & Words & Babbling & Words & Babbling & Words \\
\hline Front & 1 & 0.97 & 1 & 1.03 & 0.96 & 1.54 & 1 & 0.89 \\
\hline Central & 0.37 & 1.22 & 1.26 & 0.67 & 2.25 & 0.99 & 0.59 & 1.47 \\
\hline Back & 1.57 & 0.99 & 0.45 & 1.07 & 2.57 & 0.67 & 1.02 & 1.09 \\
\hline
\end{tabular}

Table 8: Ratios of observed to expected frequencies in Reda's babbling and first words. 
(Word: $\chi^{2}=9, \mathrm{df}=2, \mathrm{p}=0.01158$ ). Finally, Imane associated gutturals more frequently to back vowels in babbling (Fisher exact test: $p=0.000052$ ) and to central vowels in the words $\left(\chi^{2}=68, \mathrm{df}=2, \mathrm{p}<0.001\right)$.

In Reda's production, 11 of 24 possible combinations had ratios greater than 1. In babbling, although labial/back, coronal/central, dorsal/central, dorsal/back, and guttural back had ratios greater than 1, Chi-square calculations showed no significant results, indicating that there were no preferred CV associations in Reda's babbling. In words, however, Reda exhibited a very different profile. Labial consonants were preferentially associated with central vowels (Word: ratio $=1.22 ; \chi^{2}=$ 8.06, $\mathrm{df}=2, \mathrm{p}=0.01$ ), coronals to front and back vowels (Word: ratio $\mathrm{C} / \mathrm{F}=1.3$, ratio $\mathrm{C} / \mathrm{B}=1.7 ; \chi^{2}=8.5, \mathrm{df}=2, \mathrm{p}=0.01$ ) and dorsals to front vowels (Word: ratio $\left.=1.54, \chi^{2}=17.33, \mathrm{df}=2, \mathrm{p}=0.0001\right)$. For gutturals, the preferred associations were gutturals + central (Word: ratio $=1.47$ ) and gutturals + back (Word: ratio = $1.09)$ but they were not as strongly preferred as with other places of articulation $\left(\chi^{2}=5.46, \mathrm{df}=2, \mathrm{p}=0.06\right)$.

\section{Discussion}

The two Tashlhiyt children reported on here, who were followed for 15 months (i.e., during babbling and first words periods) exhibited production preferences often found in children learning other languages. This was particularly true for isolated segments, consonants and vowels. In both babbling and first words, Imane and Reda produced many oral stops, but very few liquids. They also favoured labial and coronal places of articulation, dorsals and gutturals being less heavily represented in their repertoire. The two clearly dominant vowels in babbling and in first words were [a] and [æ] which both belong to the lower left quadrant of vocalic space. Both children seem to start with easy-to-produce isolated sound types. As for syllable type, the same preference for ease of production is again present: both children in both production types produced more open syllables (CVs and Vs represented over $80 \%$ ) than closed ones. Among the rare closed syllables, CVC type was the most frequent, at around $10 \%$.

Our longitudinal design for data collection allowed us to observe the differences between the babbling period and first words. Our data confirm a diversification and increasing complexity of production with more laryngeal fricatives, rounded back vowels, closed syllables and consonant clusters in first words as compared to babbling. These trends were also described in the literature on early language development in typologically different languages.

The data also revealed a few differences that may be linked to input characteristics. First of all, the children obtained $\mathrm{C} / \mathrm{V}$ ratios close to or greater than 1.0, unlike the patterns observed in other languages such as French, Turkish, German and Tunisian Arabic (see Kern and Davis 2009). This is probably due to the ambient-language effect, given that Tashlhiyt Berber has common complex consonant clusters. The same conclusion could be drawn regarding the early use and high frequency of pharyngeal fricatives and of the vowel /i/ in our data. To test this 
hypothesis, the sound frequencies in children's production should be compared with the sound frequencies in Tashlhiyt adult language. Unfortunately, we were able to find only descriptions of Tashlhiyt phonetic and phonological systems, but no information about phoneme frequencies, either in Tashlhiyt adult language or in Tashlhiyt child-directed speech. Having this kind of information at our disposal could help us to determine more conclusively whether there is an early influence of the ambient language input (no later than the late babbling stage) on very early production.

Finally, in our analysis, we focused on testing the co-occurrence of specific consonant types with specific vowel types according to their place of articulation. Fifty percent (3/6) observed-to-expected ratios predicted by both the F/C and AP accounts were found in babbling and $83 \%(5 / 6)$ in words. These results partially contradict the $\mathrm{F} / \mathrm{C}$ account, according to which babbling is dominated by the movement of the mandible, without any independent action of other articulators. The F/C account explains these combinations as due to a slight preference for greater ease of articulation. In addition, our data showed ratios greater than 1.0 for $\mathrm{CV}$ combinations other than the favoured ones. However, in babbling, $\chi^{2}$ calculations showed a significant preference in the case of only one of these $\mathrm{CV}$ combinations, the coronal/back association in Imane's productions. In words, two other CV combinations were preferred by both children: dorsal + front and coronal + back associations. According to the AP account, all preferred combinations are preferred over others because $\mathrm{C}$ and $\mathrm{V}$ can be produced in phase. This explanation fits the preferred coronal-back associations we found in our data: these associations are mechanically independent, or constrict at the same location. But this argument does not explain the presence of dorsal + front associations in words.

In addition, the comparison between babbling and first word production has shown that in only two cases the ratios of expected associations decreased from babbling to the first words period. As we have no information about the ratio of expected associations, either in the adult language or in child-directed speech in Tashlhiyt, nothing conclusive can be said about this very small decrease: do children begin to be influenced by input characteristics, or are the changes due simply to an increase in their production capacities? At this stage, it is very difficult to say, especially if we consider Whalen et al.'s (2012) work, which shows that consonant-vowel combinations in babbling do not appear in all adult spoken corpora: the correlation between spoken corpora and babbling were significantly positive in French, uncorrelated in Mandarin and significantly negative in English. Globally, therefore, our data seem to fit the AP predictions more closely than those of the F/C approach.

This two-child longitudinal case study confirmed the preference for easy-toproduce sounds in Tashlhiyt-learning children, supporting a universal biomechanical foundation for early production patterns. However, they only partially confirm the crosslinguistic existence of preferred CV combinations. In addition, our work showed a continuity between babbling and first words, with some differences possibly explained either by an increase in production capacity and/or by the influence of input characteristics. This last hypothesis should be confirmed by studying more participants and comparing children's and child-directed speech segments and CV association frequencies. 


\section{REFERENCES}

Al-Tamimi, Jalal-eddin, and Emmanuel Ferragne. 2005. Does vowel space size depend on language vowel inventories? Evidence from two Arabic dialects and French. In Proceedings of the 9th European Conference on Speech Communication and Technology (InterspeechEurospeech 2005), 2465-2468.

Amayreh, Moussa M., and Alice T. Dyson. 2000. Phonetic inventories of young Arabic-speaking children. Clinical Linguistics and Phonetics, 14(3): 193-215.

Anjana, S., and N. Sreedevi. 2008. Phonetic characteristics of babbling in Kannada. Dissertation abstract: Research at AIISH, Vol VII: 2007-2008, 18-34.

Atkinson, Kay, Brian MacWhinney, and Carol Stoel. 1970. An experiment on the recognition of babbling. Papers and Reports on Child Language Development, 5: 1-8.

Berman, Ruth. 1977. Natural phonological process at the one-word stage. Lingua 43(1): 1-21.

Bickley, Corine. 1983. Acoustic evidence for phonological development of vowels in young children. Paper presented at the Tenth International Congress of Phonetic Sciences, Utrecht, Holland.

Boukous, Ahmed. 2011. Revitalizing the Amazigh language: Stakes, challenges and strategies. Rabat: IRCAM.

de Boysson-Bardies, Bénédicte. 1993. Ontogeny of language-specific syllabic production. In Developmental Neurocognition: Speech and Face Processing in the First Year of Life, ed. Bénédicte de Boysson-Bardies, Scania de Schönen, Peter Jusczyk, Peter MacNeilage and John Morton, 353-363. Dordrecht: Kluwer.

de Boysson-Bardies, Bénédicte, Pierre Hallé, Laurent Sagart, and Catherine Durand. 1989. A crosslinguistic investigation of vowel formants in babbling. Journal of Child Language 16 (1): $1-17$.

de Boysson-Bardies, Bénédicte, Laurent Sagart, and Catherine Durand. 1984. Discernible differences in the babbling of infants according to target language. Journal of Child Language 11(1): 1-15.

Branigan, George. 1976. Syllabic structure and the acquisition of consonants: The great conspiracy in word formation. Journal of Psycholinguistic Research, 5(2): 117-133.

Browman, Catherine P., and Louis Goldstein. 1986. Towards an articulatory phonology. Phonology Yearbook 3: 219-252.

Buhr, Robert D. 1980. The emergence of vowels in an infant. Journal of Speech and Hearing Research 23(1): 73-94.

Cataño, Lorena, Jessica A. Barlow, and Maria I. Moyna. 2009. A retrospective study of phonetic inventory complexity in acquisition of Spanish: Implications for phonological universals. Clinical Linguistics and Phonetics, 23(6): 446-472.

Chaker, Salem. 1992. Une décennie d'études berbères (1980-1990). Bibliographie critique: langue, littérature, identité. Algiers: Bouchène.

Chan, Cousin. 2001. Consonant-vowel co-occurrence in early speech development of normal Cantonese-speaking children. BSc thesis, University of Hong Kong.

Chen, Han P., and Orvis C. Irwin. 1946. Development of speech during infancy: Curve of differential percentage indices. Journal of Experimental Psychology 36(6): 522-525.

Chen, Li-Mei, and Raymond D. Kent. 2005. Consonant-vowel co-occurrence patterns in Mandarin-learning infants. Journal of Child Language 32(3): 507-534.

Chen, Li-Mei, and Raymond D. Kent. 2010. Segmental production in Mandarin-learning infants. Journal of Child Language 37(2): 341-371. 
Cissé, Ibrahima. 2014. Développement phonético-phonologique en fufulde et bambara d'enfants monolingues et bilingues : étude du babillage et des premiers mots. Doctoral dissertation, LOT, Netherlands Graduate School of Linguistics.

Coleman, John. 1996. Declarative syllabification in Tashlhiyt Berber. In Current Trends in Phonology: Models and Methods, Vol. 1, ed. Jacques Durand and Bernard Laks, 177-218. Salford: European Studies Research Institute, University of Salford.

Coleman, John. 2001. The phonetics and phonology of Tashlhiyt Berber syllabic consonants. Transactions of the Philological Society 99(1): 29-64.

Davis, Barbara. L., and Peter F. MacNeilage. 1990. Acquisition of correct vowel production: A quantitative case study. Journal of Speech and Hearing Research 33(1): 16-24.

Davis, Barbara. L., and Peter F. MacNeilage. 1995. The articulatory basis of babbling. Journal of Speech and Hearing Research 38(6): 1199-1211.

Davis, Barbara L., and Peter F. MacNeilage. 2000. An embodiment perspective on the acquisition of speech perception. Phonetica 57(2-4): 229-241.

Davis, Barbara L., Peter F. MacNeilage, and Christine L. Matyear. 1999. Intrasyllabic patterns in babbling and early speech. In Proceedings of the 14th International Congress of Phonetic Sciences, 2481-2484.

Davis, Barbara L., Peter F. MacNeilage, and Christine L. Matyear. 2002. Acquisition of serial complexity in speech production: A comparison of phonetic and phonological approaches to first word production. Phonetica 59(2-3): 75-107.

Dell, François, and Mohamed Elmedlaoui. 1985. Syllabic consonants and syllabification in Imdlawn Tashlhiyt Berber. Journal of African Languages and Linguistics 7(2): 105-130.

Dell, François, and Mohamed Elmedlaoui. 2002. Syllables in Tashlhiyt Berber and in Moroccan Arabic. Dordrecht: Kluwer.

Elbers, Loekie. 1982. Operating principles in repetitive babbling: A cognitive continuity approach. Cognition 12(1): 45-63.

Elbers, Loekie, and Josi Ton. 1985. Play pen monologues: The interplay of words and babbles in the first words period. Journal of Child Language 12(3): 551-65.

Fee, Jane, and David Ingram. 1982. Reduplication as a strategy of phonological development. Journal of Child Language 9(1): 41-54.

Fenson, Larry, Philip S. Dale, J. Steven Reznick, Donna Thal, Elizabeth Bates, Jeffrey Hartung, Steve J. Pethick, and Judy Reilly. 1993. MacArthur Communicative Development Inventories: User's guide and technical manual. San Diego: CA Singular Publishing Group.

Fudge, Erik. 1969. Syllables. Journal of Linguistics 5(2): 253-287.

Gildersleeve-Neumann, Christina E., and Barbara L. Davis. 1998. Learning English in a bilingual preschool environment: Change over time. Paper presented at the Annual Convention of the American Speech-Language-Hearing Association, San Antonio, TX.

Gildersleeve-Neumann, Christina E., Barbara L. Davis, and Peter F. MacNeilage. 2013. Syllabic patterns in the early vocalizations of Quichua children. Applied Psycholinguistics 34(1): 111-134.

Grenon, Izabelle, Allison Benner, and John H. Esling. 2007. Language-specific phonetic production patterns in the first year of life. In Proceedings of the 16th International Congress of Phonetic Sciences, vol. 3, ed. Jürgen Trouvain and William J. Barry, 1561-1564. Saarbrücken: Universität des Saarlandes.

Giulivi, Sara, Doug H. Whalen, Louis M. Goldstein, Hosung Nam, and Andrea G. Levitt. 2011. An articulatory phonology account of preferred consonant-vowel combinations. Language Learning and Development 7(3): 202-225. 
Goldstein, Louis, Dani Byrd, and Elliot Saltzman. 2006. The role of vocal tract gestural action units in understanding the evolution of phonology. In Action to language via the mirror neuron system, ed. Michael A. Arbib, 215-249. Cambridge: Cambridge University Press.

Guerssel, Mohamed. 1986. Glides in Berber and syllabicity. Linguistic Inquiry 17(1): 1-12.

Ingram, David. 1981. The emerging phonological system of an Italian-English bilingual child. Journal of Italian Linguistics 2: 95-113.

Jakobson, Roman. 1968. Child language, aphasia, and phonological universals. The Hague: Mouton. [1941]

Kent, Raymond D., and Harold R. Bauer. 1985. Vocalizations of one-year-olds. Journal of Child Language 12(3): 491-526.

Kern, Sophie, and Barbara L. Davis. 2009. Emergent complexity in early vocal acquisition: Cross-linguistic comparisons of canonical babbling. In Approaches to phonological complexity, ed. François Pellegrino, Egidio Marsico, Ioana Chirotan, and Christophe Coupé, 353-376. Berlin: Mouton de Gruyter.

Khan, Farhat. 1984. Phonological development of Urdu-speaking children. International Review of Applied Linguistics in Language Teaching 22(4): 277-286.

Konopczynski, Gabrielle. 1986. Du prélangage au langage: acquisition de la structuration prosodique. Thèse de Doctorat d'État, Université de Strasbourg II.

Koopmans-van Beinum, Florien J., and Jeannette M. van der Stelt. 1986. Early stages in the development of speech movements. In Precursors of early speech, ed. Björn Lindblom, and Rolf Zetterström, 37-50. New York: Stockton Press.

Kopkalli-Yavuz, Handan, and Sehun Topbaş. 2000. Children's preferences in early phonological acquisition: How does it reflect sensitivity to the ambient language? In Studies on Turkish and Turkic languages: Proceedings of the Ninth International Conference on Turkish Linguistics, ed. Aslı Göksel and Celia Kerslake, 289-295. Wiesbaden: Harrassowitz.

Lahey, Margaret, Judy Flax, and Gloria Schlisselberg. 1985. A preliminary investigation of reduplication in children with specific language impairment. Journal of speech and hearing disorders 50(2): 186-194.

Lahrouchi, Mohamed. 2013. À propos de I et de U en berbère : de la phonologie, de la morphologie et des phases. In Phonologie, morphologie, syntaxe; mélanges offerts à JeanPierre Angoujard, ed. Ali Tifrit, 21-30. Presses Universitaires de Rennes.

Langsdale, Teru E. 1993. Vowel production in relationship to consonant context. Unpublished master's thesis, University of Nevada, Reno.

Lee, Barbara Ching-man. 2006. Patterns of vowel and pitch productions at the babbling stage of Hong Kong infants. MPhil thesis, City University of Hong Kong.

Lee, Sue Ann S. 2003. Perceptual influences on speech production in Korean-learning infant babbling. Unpublished manuscript, Texas, Austin.

Lee, Sue Ann S., and Barbara L. Davis. 2010. Segmental distribution patterns in English infantand adult-directed speech. Journal of Child Language 37(4): 767-791.

Lee, Sue Ann S., Barbara L. Davis, and Peter F. MacNeilage. 2008. Segmental properties of input speech: A study of Korean. Journal of Child Language 35(3): 591-617.

Lee, Sue Ann S., Barbara L. Davis, and Peter F. MacNeilage. 2010. Universal production patterns and ambient language influences in babbling: A cross-linguistic study of Koreanand English-learning infants. Journal of Child Language 37(2): 293-318.

Levelt, Clara. 1996. Consonant-vowel interactions in child language. In Proceedings of the UBC International Conference on Phonological Acquisition, ed. Barbara Bernhardt, John Gilbert, and David Ingram, 229-239. Somerville, MA: Cascadilla Press. 
Levitt, Andrea G., and Jennifer G. Aydelott Utman. 1992. From babbling towards the sound systems of English and French: A longitudinal two-case study. Journal of Child Language 19(1): 19-49.

Lindblom, Björn. 1986. Phonetic universals in vowel systems, In Experimental Phonology, ed. John J. Ohala John and Jeri J. Jaeger, 13-44. New York: Academic Press.

Lipkind, Dina, Gary F. Marcus, Douglas K. Bemis, Kazutoshi Sasahara, Nori Jacoby, Miki Takahasi, Kenta Suzuki, Olga Feher, Primoz Ravbar, Kazuo Okanoya, and Ofer Tchernichovski. 2013. Stepwise acquisition of vocal combinatorial capacity in songbirds and human infants. Nature 498: 104-108.

Locke, John L. 1983. Phonological acquisition and change. New York: Academic Press.

Macken, Marlys A. 1978. Permitted complexity in phonological development: one child's acquisition of Spanish consonants. Lingua 44(2-3): 219-253.

MacNeilage, Peter F. and Barbara L. Davis.1990a. Acquisition of speech production: Frames, then content. In Attention and Performance XIII: Motor representation and control, ed. Marc Jeannerod, 453-475. Hillsdale, N.J.: Lawrence Erlbaum.

MacNeilage, Peter F., and Barbara L. Davis. 1990b. Acquisition of speech production: The achievement of segmental independence. In Speech production and speech modelling, ed. William J. Hardcastle and Alain Marchal, 55-68. Dordrecht: Kluwer.

MacNeilage, Peter F., and Barbara L. Davis. 1993. Motor explanations of babbling and early speech patterns. In Developmental neurocognition: Speech and face processing in the first year of life, ed. Bénédicte de Boysson-Bardies, Scania de Schönen, Peter Jusczyk, Peter MacNeilage and John Morton, 341-352. Dordrecht: Kluwer.

Mitchell, Pamela R., and Raymond D. Kent. 1990. Phonetic variation in multisyllabic babbling. Journal of Child Language 17(2): 247-265.

Nathani, Suneeti, and D. Kimbrough Oller. 2001. Beyond $b a-b a$ and gu-gu: Challenges and strategies in coding infant vocalizations. Behavior Research Methods, Instruments, and Computers 33(3): 321-330.

Nettelbladt, Ulrika. 1982. On phonotactic and prosodic development in normal and language disordered Swedish children. Papers and reports on child language development 21: 125-129.

Oller, D. Kimbrough. 1980. The emergence of the sounds of speech in infancy. In Child phonology 1: Production, ed. Grace H. Yeni-Komshian, James F. Kavanagh and Charles A. Ferguson, 93-112. New York: Academic Press.

Oller, D. Kimbrough. 1986. Metaphonology and infant vocalizations. In Precursors of early speech, ed. Björn Lindblom and Rolf Zetterström, 21-35. New York: Stockton Press.

Oller, D. Kimbrough. 2000. The emergence of the speech capacity. Mahwah, NJ: Lawrence Erlbaum.

Oller, D. Kimbrough, and Rebecca E. Eilers. 1982. Similarity of babbling in Spanish- and English-learning babies. Journal of Child Language 9(3): 565-577.

Oller, D. Kimbrough, Rebecca E. Eilers, A. Rebeca Neal, and Heidi K. Schwartz. 1999. Precursors to speech in infancy: The prediction of speech and language disorders. Journal of Communication Disorders 32(4): 223-45.

Oller, D. Kimbrough, and Michele L. Steffans. 1993. Syllables and segments in infant vocalizations and young child speech. In First and Second Language Phonology, ed. Mehmet Yavas, 45-62. San Diego: Singular Publishing Co.

Oller, D. Kimbrough, Leslie A. Wieman, William J. Doyle, and Carol Ross. 1976. Infant babbling and speech. Journal of Child Language 3(1): 1-11.

Olney, Rachel L., and Ellin K. Scholnik. 1976. Adult judgments of age and linguistic differences in infant vocalization. Journal of Child Language 3(2): 145-155. 
Omar, Margaret K. 1973. The acquisition of Egyptian Arabic as a native language. The Hague: Mouton.

Prater, Rex J., and Roger W. Swift. 1982. Phonological process development with MLUreferenced guidelines. Journal of Communication Disorders 15(5): 395-410.

Pye, Clifton, David Ingram, and Helen List. 1987. A comparison of initial consonant acquisition in English and Quiche. In Children's Language, ed. Katherine E. Nelson and Anne Van Kleeck, 175-190. Hillsdale, NJ: Lawrence Erlbaum.

Reeny, Roy, and N. Sreedevi, N. 2013. Nature of vowels and diphthongs in babbling of Malayalam infants. Journal of Child Language Acquisition and Development 1(2): 29-42.

Robb, Michael, and Ken M. Bleile. 1994. Consonant inventories of young children from 8 to 25 months. Clinical Linguistics and Phonetics 8(4): 295-320.

Rose, Yvan, Brian MacWhinney, Rodrigue Byrne, Gregory Hedlund, Keith Maddocks, Philip O'Brien, and Todd Warehem. 2006. Introducing Phon: A software solution for the study of phonological acquisition. In Proceedings of the 30th Annual Boston University Conference on Language Development, 489-500. Somerville, MA: Cascadilla Press.

Rosenhouse, Judith. 2000. The acquisition of Arabic as a mother tongue (mainly in Israel). Oriente moderno 1: 119-151.

Roug, Liselotte, Ingrid Landberg, and L.J. Lundburg. 1989. Phonetic development in early infancy: A study of four Swedish children during the first eighteen months of life. Journal of Child Language 16(1): 19-40.

Shi, Rushen. 1988. A universal CV tendency? Another look at the syllable structure in first language acquisition. Proceedings of the Deseret Language and Linguistic Society Symposium 14: 113-126.

Shyamala, K. C. and Basanti Devi. 2003. Developmental milestones of language acquisition in Indian languages: Kannada and Hindi. Unpublished ICSSR project.

Smith, Bruce L., Sharon Brown-Sweeney, and Carol Stoel-Gammon. 1989. A quantitative analysis of reduplicated and variegated babbling. First Language 9: 175-189.

Snow, David, and Carol Stoel-Gammon. 1994. Intonation and final lengthening in early child language. In First and second language phonology, ed. Mehmet Yavas, 81-105. San Diego: Singular Publishing Group.

Stampe, David. 1969. The acquisition of phonetic representation. In Papers from the fifth regional meeting of the Chicago Linguistics Society, ed. Robert I. Binnick, Alice Davison, Georgia Green and Jerry L. Morgan, 126-183. Chicago: Chicago Linguistics Society.

Stark, Rachel E. 1980. Stages of speech development in the first year of life. In Child phonology, Vol 1: Production, ed. Grace H. Yeni-Komshian, James F. Kavanagh and Charles A. Ferguson, 113-142 . New York: Academic Press.

Stoel-Gammon, Carol. 1985. Phonetic inventories 15-24 months: A longitudinal study. Journal of Speech and Hearing Research 28(4): 506-512.

Stoel-Gammon, Carol, and Judith Cooper. 1984. Patterns of early lexical and phonological development. Journal of Child Language 11(2): 247-271.

Stokes, Stephany F., and I. Man Wong. 2002. Vowel and diphthong development in Cantonese-speaking children. Clinical Linguistics and Phonetics 16(8): 597-617.

Sussman, Harvey M., Fred D. Minifie, Eugene H. Buder, Carol Stoel-Gammon, and Jason Smith. 1996. Consonant-vowel interdependencies in babbling and early words: Preliminary examination of a locus approach. Journal of Speech and Hearing Research 39(2): 424-433.

Teixeira, Elizabeth R., and Barbara L. Davis. 2002. Early sound patterns in the speech of two Brazilian Portuguese speakers. Language and Speech 45(2): 179-204. 
Thevenin, Deborah M., Rebecca E. Eilers, D. Kimbrough Oller, and Lawrence Lavoie. 1985. Where's the drift in babbling drift? A crosslinguistic study. Applied Psycholinguistics 6(1): 3-15.

Topbaş, Sehun. 1997. Phonological acquisition of Turkish children: implications for phonological disorders. European Journal of Disorders of Communication 32(4): 377-396.

Vihman, Marilyn M. 1992. Early syllables and the construction of phonology. In Phonological development: models, research, implications, ed. Charles Ferguson, Lise Menn and Carol Stoel-Gammon, 393-422. Timonium, MD: York Press.

Vihman, Marilyn M., Charles E. Ferguson, and Mary Elbert. 1986. Phonological development from babbling to speech: Common tendencies and individual differences. Applied Psycholinguistics 7(1): 3-40.

Vihman, Marilyn M., Marlys A. Macken, Ruth Miller, and Hazel Simmons. 1985. From babbling to speech: A reassessment of the continuity issue. Language 61(2): 397-445.

Whalen, Douglas, Sara Giulivi, Hosung Nam, Andréa G. Levitt, Pierre Hallé, and Louis M. Goldstein. 2012. Biomechanically preferred consonant-vowel combinations fail to appear in adult lexicons and spoken corpora. Language and Speech 55(4): 503-515.

Weir, Ruth H. 1966. Some questions on the child's learning of phonology. In The genesis of language: A psycholinguistic approach, ed. Frank Smith and George A. Miller, 153-172. Cambridge, MA: MIT Press.

Werker, Janet F., and Chris E. Lalonde. 1988. Cross language speech perception: Initial capabilities and developmental change. Developmental Psychology 24(5): 672-683.

Winitz, Harris, and Orvis Irwin.1958. Syllabic and phonetic structure of infants' early words. Journal of Speech and Hearing Research 1(3): 250-256.

Zhu, Hua, and Barbara Dodd. 2000. Putonghua (modern standard Chinese)-speaking children with speech disorder. Clinical Linguistics and Phonetics 14(3): 165-191.

Zink, Inge. 2005. De verwerving van de klankproductie tijdens de brabbelperiode bij vier Vlaamse kinderen [The acquisition of sound production during the babbling period by four Flemish children]. Logopedie 18(4): 13-20.

Zlatic, L., Peter F. MacNeilage, Christine L. Matyear, and Barbara L. Davis. 1997. Babbling of twins in a bilingual environment. Applied Psycholinguistics 18(4): 453-469.

Zlatin, Marsha A. 1975. Explorative mapping of the vocal tract and primitive syllabification in infancy: The first six months. Paper presented at the American Speech and Hearing Association Convention, Washington, D.C.

Zmarich, Claudio, and Renzo A. Miotti. 1999. The frequency of consonants and vowels and their co-occurrences in the babbling and early speech of Italian children. Proceedings of the 15th International Congress of Phonetic Sciences, 1947-1950. Sydney, Australia. 